\title{
Drivers for University Research Performance: Investigating the Researchers' Dynamics
}

\author{
Kamarulzaman Ab. Aziz ${ }^{1}$, Hezlin Harris ${ }^{1}$, Stanley Richardson ${ }^{1}$ and Nor Azlina Ab. Aziz ${ }^{2}$ \\ ${ }^{1}$ Faculty of Management, Multimedia University, Cyberjaya, Malaysia \\ ${ }^{2}$ Faculty of Engineering Technology, Multimedia University, Melaka, Malaysia
}

\begin{abstract}
Universities provide the foundations for a nation's social, cultural, economic and technological progress. Beside the academic programmes offered by the universities that build the human capital, research activities are the other pillar of academia that help to drive a nation's progress. Andersson (2010) identified research environment and researchers dynamics as the key factors that impact the quality of research in universities. The aim of this paper is to investigate the researchers' dynamics resulting in excellent research performance by a university, and hence to derive lessons regarding university research performance. Specifically, the paper explores researchers' profiles in terms of their achievements over the past five years, their attributes, behaviour and attitude. This was achieved by using a case study approach (Eisenhardt, 1989 and Yin, 1994). The identified top commercialisation producer among the universities in Malaysia, namely Universiti Teknologi Malaysia (UTM), was selected for the case study. This paper highlights the findings.
\end{abstract}

Keywords: researcher behavior, university, Malaysian case study.

\section{Introduction}

Globally, the importance of universities and their research activities has been widely recognised (Candell \& Jaffe, 1999). According to Damon (2011), "From a standpoint of social policy, colleges and universities should strive to enhance welfare by producing an educated citizenry, a qualified and motivated workforce, and a continuing stream of creative ideas and conceptual breakthroughs in terms of medical technology, scientific advancement, reconsideration of appropriate roles for social institutions, reinterpretations of literature and history, and potential methods of resolving differences peacefully. Universities, collectively, should provide upward mobility for the population, providing opportunities for the disadvantaged to share in the production and consumption of the nation's wealth.
Individually, universities must deliver on the promise to provide the basis for "the examined life" and, possibly, to enhance the student's lifetime income by more than the cost of the education."

Universities in general are a critical component of national systems of innovation. Being one of the major contributors to the generation and transmission of knowledge within the systems, universities are hubs of discovery and creativity. Ideas can be shared and discussed in an open and tolerant environment. They are also centres of excellence where industries can resort to for their R\&D needs. Universities house expertise in variety of fields, foster relationships with stakeholders of the regions where they locate, conduct research and training, providing the foundations for a

Copyright (C) 2012 Kamarulzaman Ab. Aziz, Hezlin Harris, Stanley Richardson and Nor Azlina Ab. Aziz. This is an open access article distributed under the Creative Commons Attribution License unported 3.0, which permits unrestricted use, distribution, and reproduction in any medium, provided that original work is properly cited. Contact author: Kamarulzaman Ab. Aziz E-mail: kamarulzaman.aziz@mmu.edu.my 
nation's social, cultural, economic and technological progress.

\section{Universities and Research}

The World Bank (2000) recognised that universities play an important role in improving the lives of individuals and society, enabling higher wages and productivity, ultimately driving society's independence and initiative. James (1990) identified five goals for universities;

- Drive research and keep teaching loads low

- Balancing the quantity of undergraduate and postgraduate students

- Recruit better quality students

- Balancing class size and provision of teaching support services to maintain quality

- Balancing both teaching and research quality.

Massy (1996) noted that universities in their effort to attain prestige and recognition have become more independent, entrepreneurial and placing more emphasis on research. Andersson (2010) identified the key factors that impact the quality of research in universities to be the research environment and researchers dynamics. Damon (2011) defines "research" as, "the time the scholar spends in contemplation". The scholar's time is an input to the production process, but contemplation may be seen as the research process itself. We also find the term "research" being used to refer to a paper written by a scholar. This is an output of the production process. It is appropriate to distinguish among: (a) spending time on research (an input), (b) conducting study or organising one's thoughts (the process), and (c) communicating the results of the study."
The OECD (1994) defines "research" as: "creative work undertaken on a systematic basis in order to increase the stock of knowledge, including knowledge of man, culture and society, and the use of this stock of knowledge to devise new applications." March (1991) differentiates between research that explores new potentials and that which exploits known findings. The World Bank (2000) describes "research universities" as, "Their overriding goals are achieving research excellence across many fields and providing high-quality education. They pursue these goals by having relatively light faculty teaching loads, emphasizing research accomplishments in recruitment and promotion decisions, adopting international standards for awarding degrees, and being highly selective in the students they admit. They are most closely connected to advances in knowledge, monitoring break-through in many fields and investigating ways to exploit important results for social and private gain."

Lamari and Jacob (2011) studied factors associated with research productivity and found that other variables such as age, gender, provincial government funding, federal research agency funding, and international collaboration all have significant effect on researchers productivity. Roca, Bikfalvi, Simon and Alcoba (2011) recognize the following as factors that may affect research performance:

- Government policies

- Universities objectives and procedures

- The unit or department the researcher belongs to

- The researcher's own preferences and attitudes

- The research topic 
- The research type

- Incentive systems

\section{Malaysian Universities}

The Ministry of Higher Education (MOHE) reported the research commercialisation achievement by the Malaysian public universities up till August 2008 (Table 1), which is the most current report available at the time of this study. According to the report, the 16 public universities in Malaysia had only managed to commercialize 58 products out of the 313 identified with commercial potential. The achievements among the private universities were found to be no better than what was seen from the public ones. It was clear that there is a need to address the situation and drive the universities to better performance levels.

At the individual IHL/university level, the ecosystem for $R \& D$ and business creation would commonly include the following:

- Infrastructure and infostructure for R\&D activities (e.g.: library, databases, laboratories, equipment, etc.)

- Organizational structure

○ R\&D Management (e.g.: Research Management Centre)

o Commercialization Management (e.g.: Business Unit, Commercialization Centre, Technology Licensing Office (TLO), Innovation Centre, Technology Transfer Office (TTO), Training and Consulting Unit, Business Creation Office, Incubator, etc.)

- Human capital

- Policies (e.g.: R, D \& C Roadmap, training and development programmes, incentives, KPIs, funding, etc.)
There are a number of funds, grants and incentives made available by the government to enable innovation and business creation among the universities. Following are some examples of the government initiatives:

- Cradle Investment Programme (CIP) (www.cradle.com.my)

o Seed funding for turning technology oriented ideas into commercial ventures. The programme also includes a subprogramme for university spin-outs and start-ups; University Cradle Investment Programme (U-CIP).

- Demonstrator Application Grant Scheme (DAGS)

- Managed by the Ministry of Science, Technology and Innovation (MOSTI). It is seed funding for ICT-based community pilot projects.

- eContent Fund

○ Managed by MOSTI. Fund for content creation projects.

- InnoFund

- Managed by MOSTI. Fund for innovation commercialization projects.

- Multimedia Super Corridor (MSC) Malaysia Intellectual Property (IP) Grant Scheme

- Managed by Multimedia Development Corporation (MDeC). The scheme provides subsidy up to $70 \%$ of IP protection costs. However, this is done in reimbursement basis and application should be made after the process had been done.

- $\quad$ MSC Malaysia R\&D Grant Scheme (MGS) 
○ Managed by MDeC. The scheme provides grant for R\&D activities conducted in Malaysia.

- eScience Fund

- Managed by MOSTI. The fund for R\&D projects in priority areas largely targeted by universities.

- Techno Fund

- Managed by MOSTI. Fund for precommercialization projects and IP acquisition.

- MSC Malaysia Technopreneur Pre-Seed Fund Programme
○ Managed by MDeC till 2009. This was transferred to CIP and rebranded as CIP Catalyst pre-seed fund programme. The fund is for technopreneur start-up creations.

It was reported that under the 9th Malaysia Plan (2006 - 2010), the Malaysian government invested a total of RM3.101 billion in the form of R\&D grants. Meanwhile, under the 10th Malaysia Plan (2011 - 2015), the government allocated RM741 million for R\&D among the universities for the first two years of the five year plan. The allocation was to be managed by the Ministry of Higher Education. In line with the new directives, the ministry announced a set of 4 R\&D schemes to utilize the RM741 million allocations (See Table 2).

Table 1: University Research Commercialisation until August 2008 (MOHE, 2008)

\begin{tabular}{|c|c|c|c|c|c|}
\hline Universities & Patent & $\begin{array}{l}\text { Trade } \\
\text { mark }\end{array}$ & $\begin{array}{l}\text { Total } \\
\text { Commercialise } \\
\text { d Products }\end{array}$ & $\begin{array}{l}\text { Total R\&D with } \\
\text { Potential for } \\
\text { Commercialised } \\
\text { Products }\end{array}$ & $\begin{array}{l}\text { Total } \\
\text { No. of IP }\end{array}$ \\
\hline $\begin{array}{l}\text { Universiti Teknologi Malaysia } \\
\text { (UTM) }\end{array}$ & 9 & 28 & 6 & 110 & 153 \\
\hline Universiti Putra Malaysia (UPM) & 12 & 27 & 16 & 15 & 70 \\
\hline $\begin{array}{l}\text { Universiti Kebangsaan Malaysia } \\
\text { (UKM) }\end{array}$ & 3 & 20 & 0 & 33 & 56 \\
\hline Universiti Malaya (UM) & 0 & 11 & 3 & 31 & 45 \\
\hline Universiti Sains Malaysia (USM) & 11 & 4 & 15 & 9 & 39 \\
\hline Universiti Teknologi Mara (UiTM) & 5 & 22 & 8 & 0 & 35 \\
\hline Universiti Malaysia Pahang (UMP) & 0 & 0 & 1 & 29 & 30 \\
\hline Universiti Malaysia Sabah (UMS) & 0 & 0 & 0 & 26 & 26 \\
\hline Universiti Utara Malaysia (UUM) & 0 & 0 & 0 & 21 & 21 \\
\hline $\begin{array}{l}\text { Universiti Tun Hussein Onn } \\
\text { Malaysia (UTHM) }\end{array}$ & 0 & 0 & 3 & 16 & 19 \\
\hline $\begin{array}{l}\text { Universiti Malaysia Sarawak } \\
\text { (UNIMAS) }\end{array}$ & 0 & 8 & 0 & 4 & 12 \\
\hline $\begin{array}{l}\text { Universiti Islam Antarabangsa } \\
\text { Malaysia (UIAM) }\end{array}$ & 0 & 2 & 2 & 4 & 8 \\
\hline $\begin{array}{l}\text { Universiti Pendidikan Sultan Idris } \\
\text { (UPSI) }\end{array}$ & 0 & 0 & 0 & 8 & 8 \\
\hline $\begin{array}{l}\text { Universiti Malaysia Terengganu } \\
\text { (UMT) }\end{array}$ & 0 & 0 & 2 & 4 & 6 \\
\hline Universiti Malaysia Perlis (UniMAP) & 0 & 0 & 2 & 3 & 5 \\
\hline $\begin{array}{l}\text { Universiti Teknikal Malaysia Melaka } \\
\text { (UTEM) }\end{array}$ & 0 & 0 & 0 & 0 & 0 \\
\hline Total & 40 & 122 & 58 & 313 & 533 \\
\hline
\end{tabular}


Table 2: $1^{\text {th }}$ Malaysia Plan Ministry of Higher Education R\&D Schemes (Source: MOHE)

\begin{tabular}{|c|c|c|}
\hline No. & Scheme & Allocation (2011 - 2012) \\
\hline 1 & Fundamental Research Grant Scheme (FRGS) & 300 million \\
\hline 2 & $\begin{array}{ll}\text { a. } & \text { Exploratory Research Grant Scheme (ERGS) } \\
\text { b. } & \text { Long-Term Research Grant Scheme (LRGS) } \\
\text { c. } & \text { Prototype Research Grant Scheme (PRGS) }\end{array}$ & 300 million \\
\hline 3 & Research Incentive & 41 million \\
\hline 4 & MOHE Special Project & 100 million \\
\hline & TOTAL & 741 million \\
\hline
\end{tabular}

There are three new aspects of the schemes, namely, the ERGS, LRGS and PRGS. Previously, the Ministry only had one R\&D grant scheme_the FRGS. The introduction of ERGS, LRGS and PRGS reflects the government's desire to enhance the research, development and commercialization activities among the universities. The three new schemes bridge the gap between university R\&D activities and the programmes in place to drive commercialization and business creation.

In terms of the development of commercialization efforts in the Malaysian higher education sector, the trend has been; i) establishment of private universities, ii) establishment of consultancy centres, iii) emphasizing research - identification of research agenda, creation of "Research University" and "Apex University" status for the public universities and the establishment of research management centres, and iv) emphasizing research commercialization this was seen more from government agenda, e.g.: the RM 191.5 billion budget announced for 2010 with the aim to create an economy based on innovation, where university R, D \& $\mathrm{C}$ are one of the key success factors.

The importance of research and related activities has been recognized, at least by Malaysian academics. For example, Nordin (2001) pleaded that all Malaysian universities should be "... performing cutting edge research and commercializing its findings and innovations" indicated by the number of commercial ventures initiated, patents awarded, research papers published and the number of PhDs produced. Among the Malaysian universities, Universiti Teknologi Malaysia (UTM) has had the highest research success as measured by the four domains presented in Table 1. This paper intends to investigate the researchers' dynamics behind UTM success.

\section{The Aim}

The aim of this paper is to investigate the researchers' dynamics resulting in UTM's success, and hence to derive lessons regarding university research performance for other Malaysian institutions. Specifically, the paper explores UTM researchers' profiles in terms of their achievements over the past five years, and their attributes, behaviour and attitude.

\section{Methodology}

Using a case study approach (Eisenhardt, 1989 and Yin, 1994), the top commercialization producer among the Malaysian universities were selected, namely Universiti Teknologi Malaysia (UTM). Yin (2003) (p. 5) identified six types of case studies: i) "A single-case study focuses on a single case only, ii) multiple-case studies, however, include two or more cases within the same study. These multiple cases should be selected so that they replicate each other either predicting similar results (literal replication) or contrasting results for predictable reasons (theoretical replication), iii) An exploratory case study (whether based on single or multiple cases) is aimed at defining the questions and hypotheses of a subsequent study (not necessarily a case study) or at determining the feasibility of the 
desired research procedures, iv) A descriptive case study presents a complete description of a phenomenon within its context, v) An explanatory case study presents data bearing on cause-effect relationships - explaining how events happened." Thus, this study adopted the descriptive case-study methodology and multiple sources of data were used. Specifically, the common types of case study sources of evidence as recognized by Stake (1995) and Yin (1994) are, namely; survey, documents, archival records, interviews and observation. Yin also argued that the relative size of the sample whether 1,10 or 100 cases does not determine the quality of the study.

A survey was developed to explore the researchers' profile in terms of their behaviour and attitude. Firstly, their research achievements for the past five years were determined in terms of conducting research, producing intellectual properties and commercialized output. The researchers were then profiled further in terms of their attitude, time management and behaviour. The survey also captured the researchers' opinion on aspects related to research commercialization from the university and the government. Lastly, the survey investigates the reasons for not conducting research, producing intellectual properties and commercialized output. The survey was distributed to 150 identified researchers in UTM and 52 were collected back. The sampling strategy used was reputational or snowball sampling (McMillan and Schumacher, 1997). According to Teddlie and Yu (2007), when using purposive sampling such as reputational sampling, the sample sizes are typically small, often 30 cases or less. The data collection period was throughout the months of January, February and March, 2011.

\section{The Case}

Universiti Teknologi Malaysia (UTM), with its main campus in Johor and a smaller campus in Kuala Lumpur, is one of the original research universities. It is one of the major universities in Malaysia, with 2000 academic staff, around 21000 undergraduate and 8000 postgraduate students. It has 14 faculties, 1 language academy, 5 schools for graduate studies and 1 school for continuing education. Its history can be traced back to 1904 as the country's first technical school. The school evolved into a college, then an institute and on 1st April 1975 it was upgraded to Universiti Teknologi Malaysia. UTM's mission is to lead in the development of creative and innovative human capital and advanced technologies that will contribute to the nation's wealth creation.

UTM's structure for research, development and commercialization is arranged along the lines of research centres which specialize in a particular research area. Firstly, the eleven Research Alliances in sustainability, infocomm, water, cybernetics, biotech, construction, materials and manufacturing, k-economy, energy, transportation and nanotechnology. Research Alliances are associations of centres of excellences, laboratories, professors and groups of researchers in UTM. The Research Alliances aim to conduct research (knowledge discovery, dissemination and commercialization) in the respective multidisciplinary research areas. In other words, the structure allows sharing of resources. The sharing of resources however must be coordinated for efficiency and effectiveness. UTM also has 28 Centres of Excellences as shown in Table 3 . The overall management of research is carried out by the Research Management Centre (RMC), which also maintains a Directory of Researchers and a List of R\&D Products.

Other than the above, UTM has a number of initiatives that further contribute towards enhancing the R\&D. Following are a number of those key initiatives:

- Universiti Teknologi Malaysia Institutional Repository (UTM-IR) is a centralized digital archive managed by the university's library where research output of UTM researchers are collected and preserved. 
UTM-IR is UTM's open access initiative where the collection of scholarly materials by UTM's researchers are showcased and shared to further drive research in Malaysia.

- UTM Idea Bank is an interactive forum that allows the students, staff and UTM partners to submit innovative and creative ideas to the university.

- UTM's Technovation Park was officially launched in August 1995 and acquired Multimedia Super Corridor (MSC) status in December 2002. The park is registered with the Association of University Related Research Parks (AURP) and the National Business Incubation Association (NBIA). The Park was designed to provide a comprehensive framework for the development of technology enterprise especially in technology and biotech development. The emphasis is through smart partnership with industry partners, it is self-sustainable and beneficial to UTM academics and students.

The significance of the structure to drive R\&D in UTM discussed above can be seen in the accumulated IPs as shown in Table 4.

Table 3: Centres of Excellences

\begin{tabular}{|l|l|}
\hline No. & Centres \\
\hline 1. & Advanced Information Technology Institute (AITI) \\
\hline 2. & Automotive Development Centre (ADC) \\
\hline 3. & Advanced Photonic Science, Institute of (APSI) \\
\hline 4. & Centre for Artificial Intelligence and Robotics (CAIRO) \\
\hline 5. & Centre for Advanced Software Engineering (CASE) \\
\hline 6. & Centre of Electrical Energy Systems (CEES) \\
\hline 7. & Centre for Technology Policy \& International Studies (CENTEPIS) \\
\hline 8. & Centre for the Study of Built Environment in the Malay World (KALAM) \\
\hline 9. & Centre for Lipids Engineering Applied Research (CLEAR) \\
\hline 10. & Centre for Real Estate Studies (CRES) \\
\hline 11. & Chemical Engineering Pilot Plant (CEPP) \\
\hline 12. & Coastal and Offshore Engineering Institute (COEI) \\
\hline 13. & Composite Centre (CC) \\
\hline 14. & Construction Technology \& Management Centre (CTMC) \\
\hline 15. & Ibnu Sina Institute for Fundamental Science Studies (IIS) \\
\hline 16. & Institutes of Environmental \& Water Resource Management (IPASA) \\
\hline 17. & Institute for Geo-Spatial Science and Technology (INSTEG) \\
\hline 18. & Institute of High Voltage \& High Current (IVAT) \\
\hline 19. & Gas Technology Centre (GASTEG) \\
\hline 20. & Marine Technology Centre (MTC) \\
\hline 21. & Wireless Communication Centre (WCC) \\
\hline 22. & Steel Technology Centre (STC) \\
\hline 23. & Photonics Technology Centre (PTC) \\
\hline 24. & Institute of Sultan Iskandar (ISI) \\
\hline 25. & Institute of Noise \& Vibration (IKG) \\
\hline 26. & Centre of Rural Planning Studies (PKPLB) \\
\hline 27. & Advanced Information Technology Institute (AITI) \\
\hline 28. & Automotive Development Centre (ADC) \\
\hline
\end{tabular}


Table 4: Accumulated IP until 5/1/2011 (Source: UTM)

\begin{tabular}{|l|l|l|}
\hline \multicolumn{2}{|c|}{ Category } & Total \\
\hline \multirow{2}{*}{ Patent } & Filing & 234 \\
\cline { 2 - 3 } & Granted & 15 \\
\hline Copyright & 329 \\
\hline Industrial Design & 3 \\
\hline Trademark & 40 \\
\hline Utility Innovation & 5 \\
\hline \multicolumn{2}{|c|}{ TOTAL } & 626 \\
\hline
\end{tabular}

\section{The Findings}

Out of the 52 respondents, half are male and half are female, with academic qualifications ranging from Bachelor (5.8\%), Masters (48.1\%), PhD (42.3\%) and others (3.8\%). The positions range from tutor (19.2\%), lecturer (9.6\%), senior lecturer (23.1\%), research fellow $(5.8 \%)$, associate professor $(15.4 \%)$ to professor $(7.7 \%)$ and others (19.2\%). See Figure 1.

Out of the 52 respondents, 38 or $73 \%$ reported to have conducted research work within the past five years (2006 - 2010). 17 or $32.7 \%$ reported to have conducted research work and the output have led to intellectual property rights (IPR) filing within the past five years. Furthermore, 11 or $21.1 \%$ reported to have conducted research work and the output have been commercialized within the past five years. This distribution of research indicates that almost three-quarters of the surveyed respondents were involved in research work within 2006 to 2010 while one-quarter were not. Out of those threequarter active researchers, less than half of their research output had led to IPR filing. The proportion of research output commercialized was only one-third of those active researchers. This suggests that there is a decreasing trend as they move along the research, development and commercialization spectrum. This reflects the evolution of the focus areas from the Malaysian government for the higher education sector.

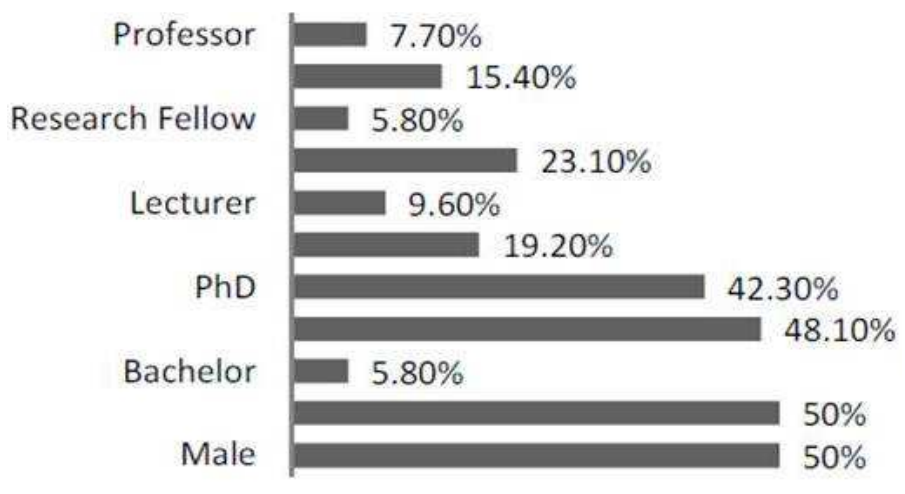

Figure 1: Respondents' Demographics

Referring to Figure 2, only $30.8 \%$ of the researchers have industry experience. It is common that academics have to juggle research with teaching and administrative works. $21.2 \%$ of the respondents teach undergraduate programmes, only 5.8\% teach postgraduate programmes only and $46.2 \%$ teach both levels. More than half of the researchers (67.3\%) hold administrative positions at various levels, $25 \%$ serve in 
national academic/professional bodies and $11.5 \%$ serve in international bodies. Less than half of them (46.2\%) normally conduct one research project only at one time, $42.3 \%$ have a portfolio of research projects and only $11.5 \%$ normally do not have any research projects.

Figure 3 highlights the common roles the researchers have taken in their research projects within the past five years.

Figure 4 highlights the different types of research projects the researchers were involved in within the past five years (2006 2010). About half of the researchers $(51.90 \%)$ utilize their postgraduate work as their research projects and most of these
(48.10\%) are applied research. Basic research accounts for slightly less than onethird $(30.80 \%)$ of their research projects. Less than half $(40.40 \%)$ of these research projects receive funding and only 5.805 without funding. Collaborating with internal and local external parties is most common with $26.90 \%$ and $23.10 \%$, respectively. There are still $11.50 \%$ of them who prefer to conduct their projects individually.

Figure 5 highlights the different sources of funds for the research projects the researchers were involved in within the past five years $(2006-2010)$. Almost half of the research projects are funded by the government (federal) and university internal research fund.

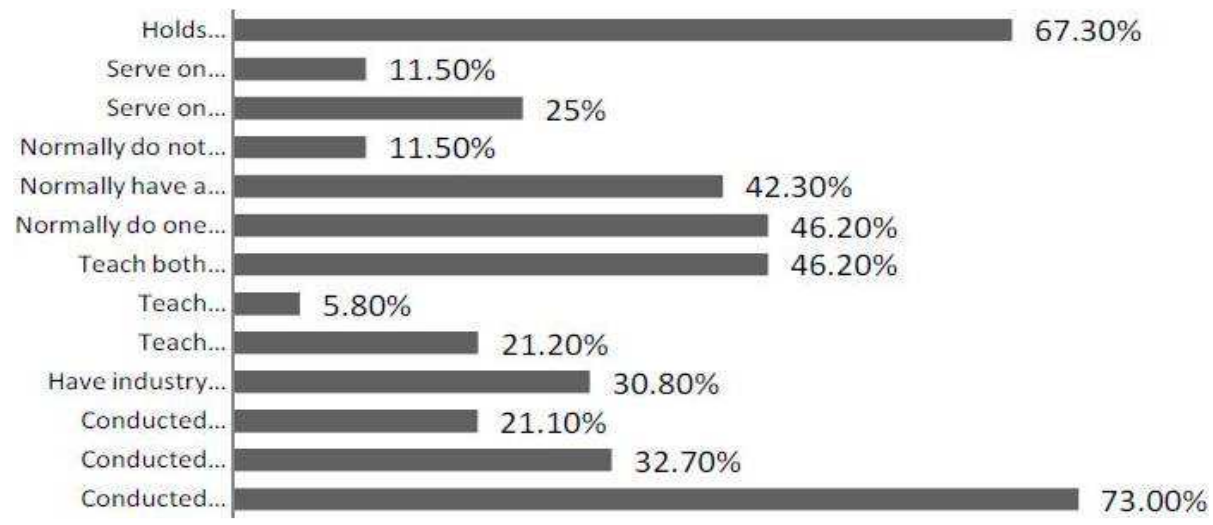

Figure 2: Research Achievements and Attributes

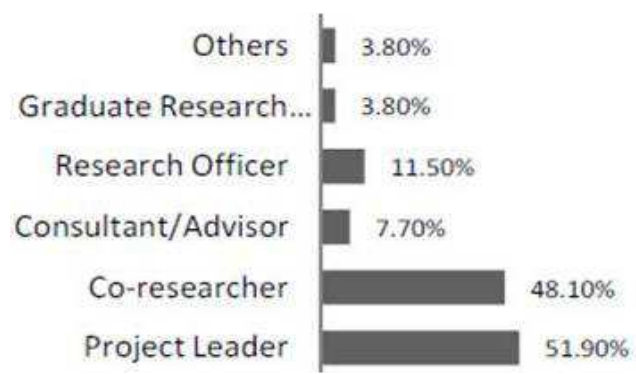

Figure 3: Roles in Research Projects

Sixteen statements were used to capture the respondents' attitude related to research, development and commercialization activities. The respondents were asked to rate the statements on a Likert-scale $(1=$ Totally Disagree, 2 = Somewhat Disagree, $3=$ Somewhat Agree, 4 = Totally Agree). Figure 6 shows the mean bar chart of each statement 
pertinent to the researchers' attitude. Based on the mean distribution, four statements were rated among the highest, which include the respondents' preference to collaborate in research and they also felt that they needed more training and experience to turn their research into commercial value and also to become a good researcher. In addition, they expressed that they did research because it was intrinsic to the university. It is important to note that there seems to be a preference towards teaching. Career advancement, personal goals and university's interest all seem to contribute towards the importance of research. In terms of guiding their research areas, own interest seems to be more important than commercial value or career advancement considerations.

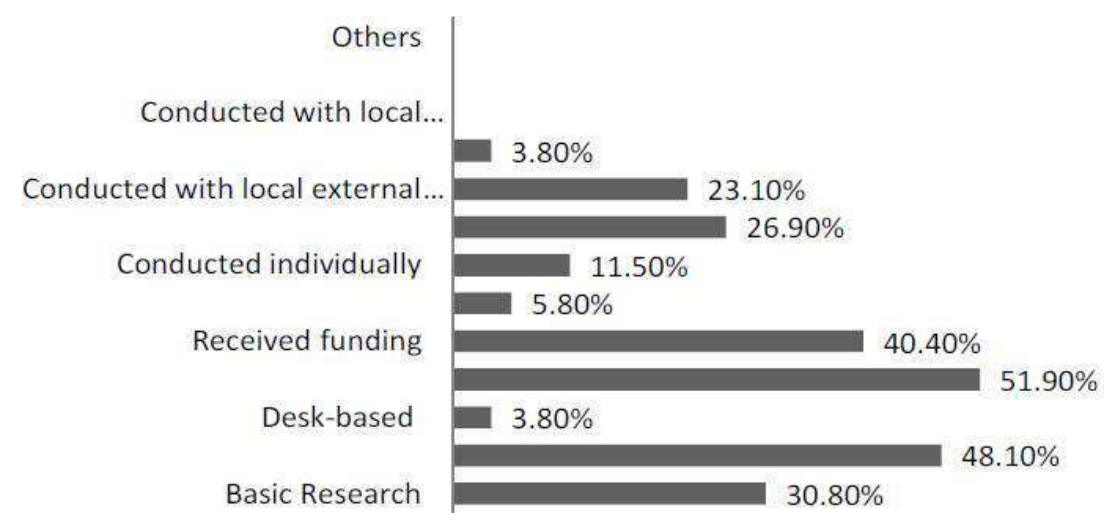

Figure 4: Types of Research Projects

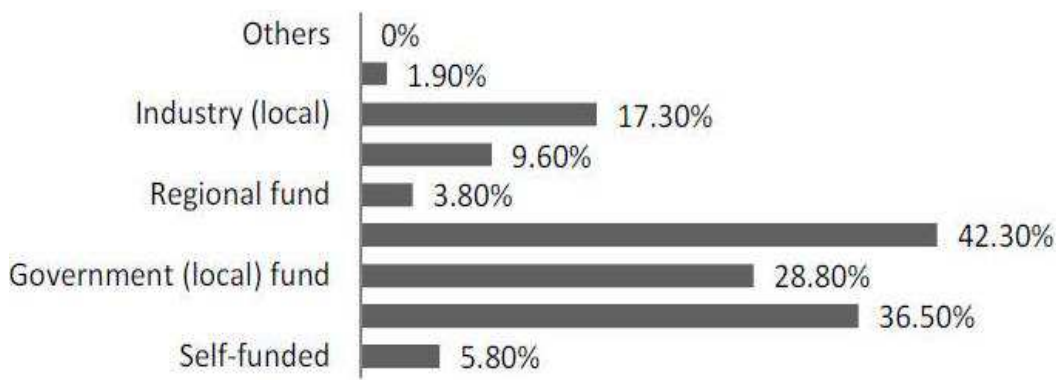

Figure 5: Funding for the Research Projects

Six statements were also asked to be given the respondents in order to capture their time management. They were required to rate the six statements using the Likert-scale $1=$ Totally Disagree, $2=$ Somewhat Disagree, 3 = Somewhat Agree, 4 = Totally Agree). Figure 7 summarizes the researchers' behaviour. Making sure there is time for research received the highest mean but fell within somewhat disagree to somewhat agree. This is closely followed by "more time was spent on administrative work and teaching than research". Generally, the respondents were tied up with administrative work and teaching but tried to balance between work and research. This scenario is supported by the lowest mean received for doing research only when they had the time for it. This reflects the good time management practised by the respondents in balancing work and research.

Six Likert-scale $(0=$ Not available, $1=$ Never, $2=$ Rarely, 3 = Often, 4 = Always) statements were used to capture the respondents' behaviour related to aspects that influence 
their research, development and commercialization activities. Utilizing the research facilities provided by the university is the most common behaviour among the respondents and receiving financial incentives is the least. Figure 8 summarizes the researchers' behaviour.

Another six Likert-scale $(0=$ not available, 1 = Totally Disagree, 2 = Somewhat Disagree, 3 = Somewhat Agree, $4=$ Totally Agree) statements were used to capture the respondents' opinion on how much of the same aspects actually drive the research activities in the university. Figure 9 indicates the mean of researchers' opinion with regards to the aspects that actually drive the research activities in the university. Generally, aspects such as university policies, strategic roadmap, research facilities and training programmes are actually the driver of the research activities in the university. These are the aspects rated among the highest by the researchers. Financial incentives and support by the university are considered to be the least factor in driving the research activities.

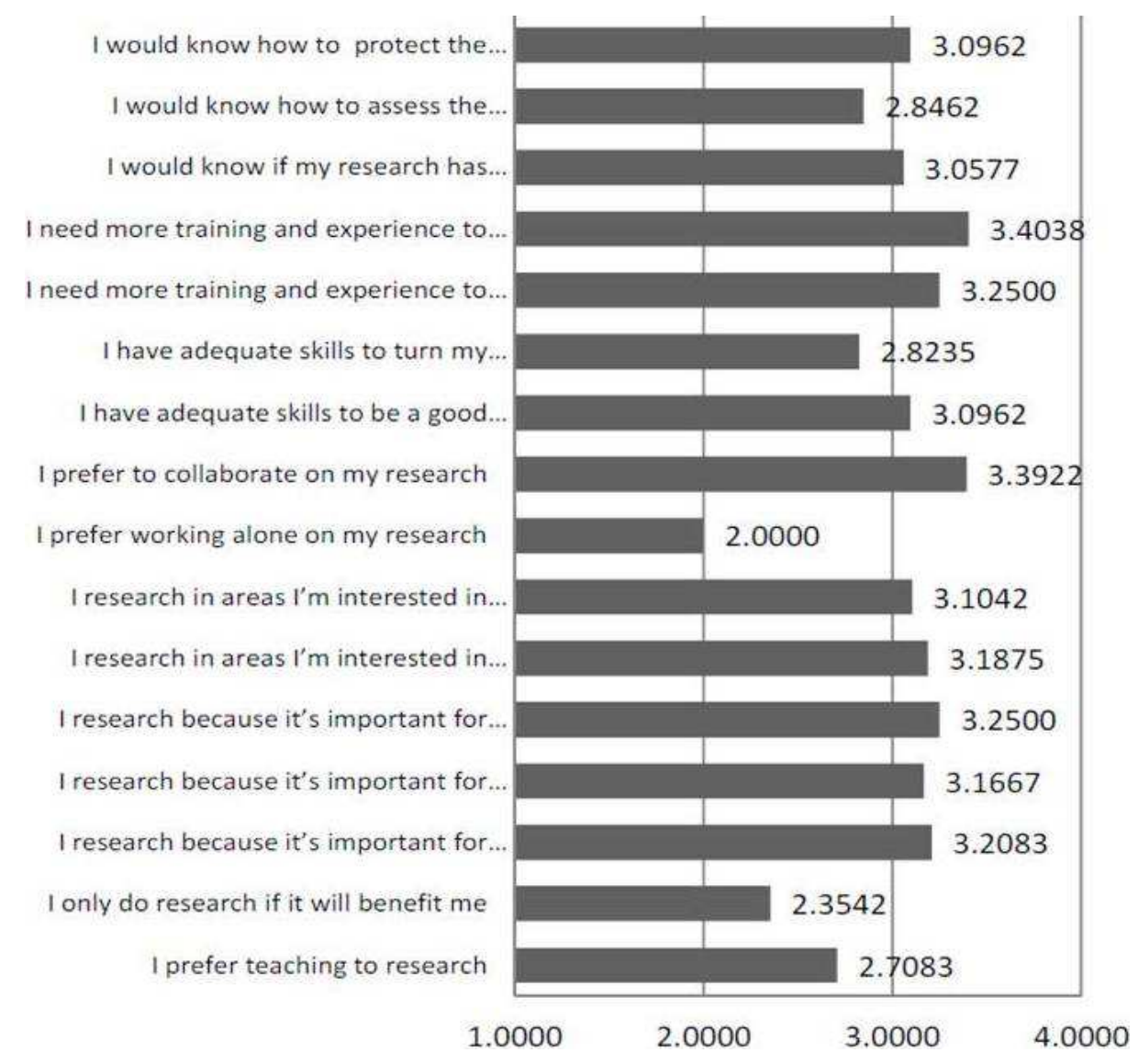

Figure 6: Researchers' Attitudes

Another six Likert-scale ( 0 = Don't Know $/$ Not Sure, 1 = Totally Disagree, 2 = Somewhat Disagree, 3 = Somewhat Agree, 4 = Totally Agree) statements were used to capture the respondents' opinion on how much of the same aspects provided by the government actually drive the research activities (refer to Figure 10). Generally, all aspects provided by the government that drive the university's research activities were rated between 
somewhat disagree and somewhat agree. These data depict neither a strong nor weak opinion with regards each aspect such as financial incentives, financial support, training programmes, policies, strategic roadmap or research facilities that drive research activities. This may suggest that the researchers believed that those six aspects were still insufficient at the government level in driving research activities.

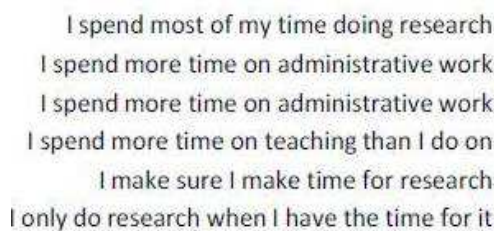

I only do research when I have the time for it

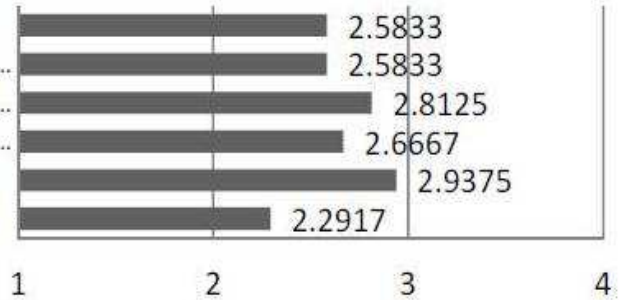

Mean

Figure 7: Researchers' Time Management

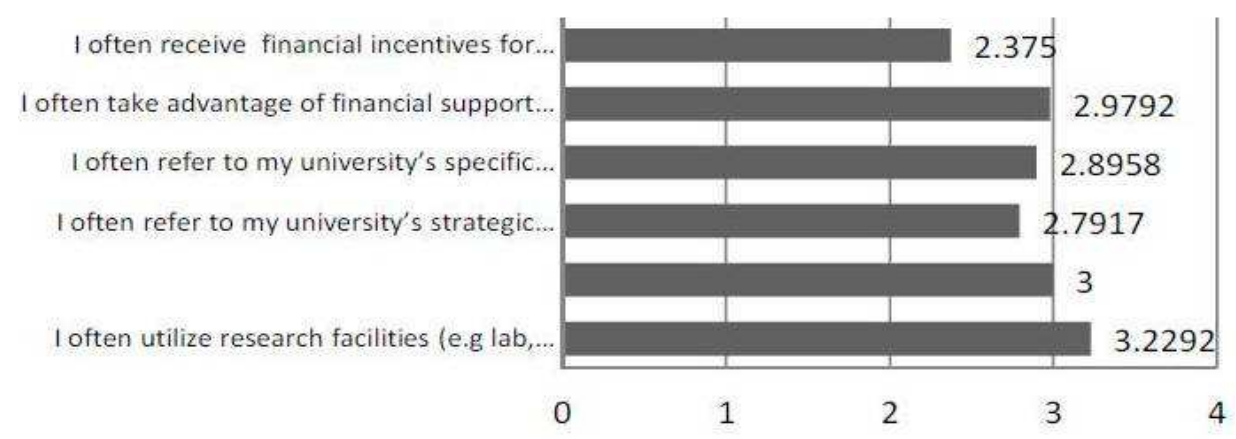

Mean

Figure 8: Researchers' Behaviour

The respondents that answered "No" to having conducted research over the past five years (2006 - 2010) chose the following reasons as in Figure 11. The most common reason for not being an active researcher was due to sabbatical, maternity or study leave. The other common reasons include having too much teaching and administrative workload and lacking training and expertise and fund to do research.

The respondents that answered "No" to having research output led to intellectual property rights (IPR) filing and "No" to having commercialized research output within the past five years (2006 - 2010), chose the following reasons as shown in Figure 12. 


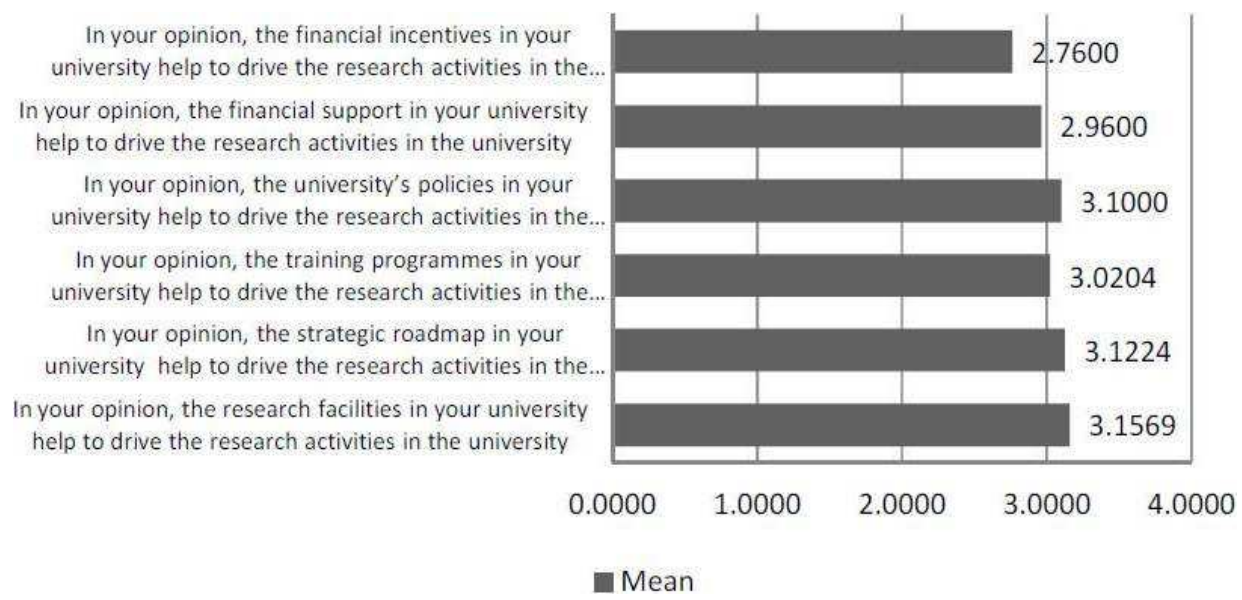

Figure 9: Researchers' Opinion - University

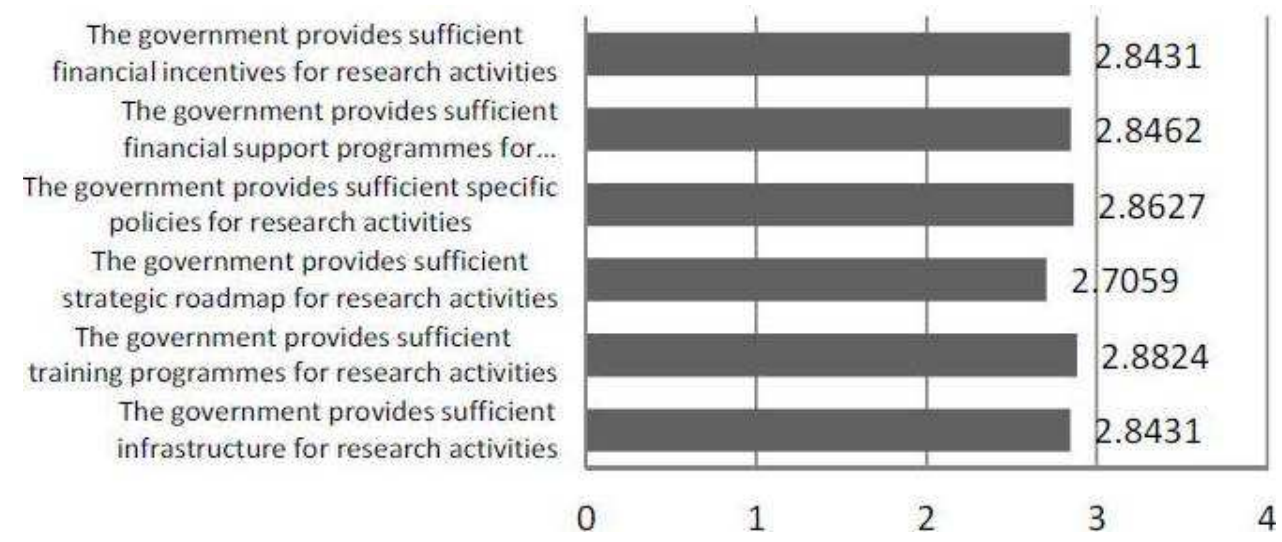

Figure 10: Researchers' Opinion - Government

\section{Discussion}

This research used the descriptive case study approach (see section 2), thus a complete description of UTM within its research context has been presented. Action research (see Rapoport, 1970) was inappropriate: data used came from the 52 researchers who completed this questionnaire. Clearly, this is a self-selected sample, but as it is $33 \%$ of the 150 UTM identified researchers (January to march 2011), it would seem to be representative. Figure 1 shows a wide range of ranks and qualifications. Future research could produce a larger sample, perhaps also by using interviewing (but the need for confidentiality would probably inhibit many respondents afraid of criticism).

The researchers hope that this paper will encourage the production, publication and use of case studies in newly developing countries, e.g., members of the ASEAN. Case studies are notoriously America-centred. "Only around a third of those published deal with an issue outside of America. Just 14\% deal with a cross-border issue in any way" (Anon, 2011). 


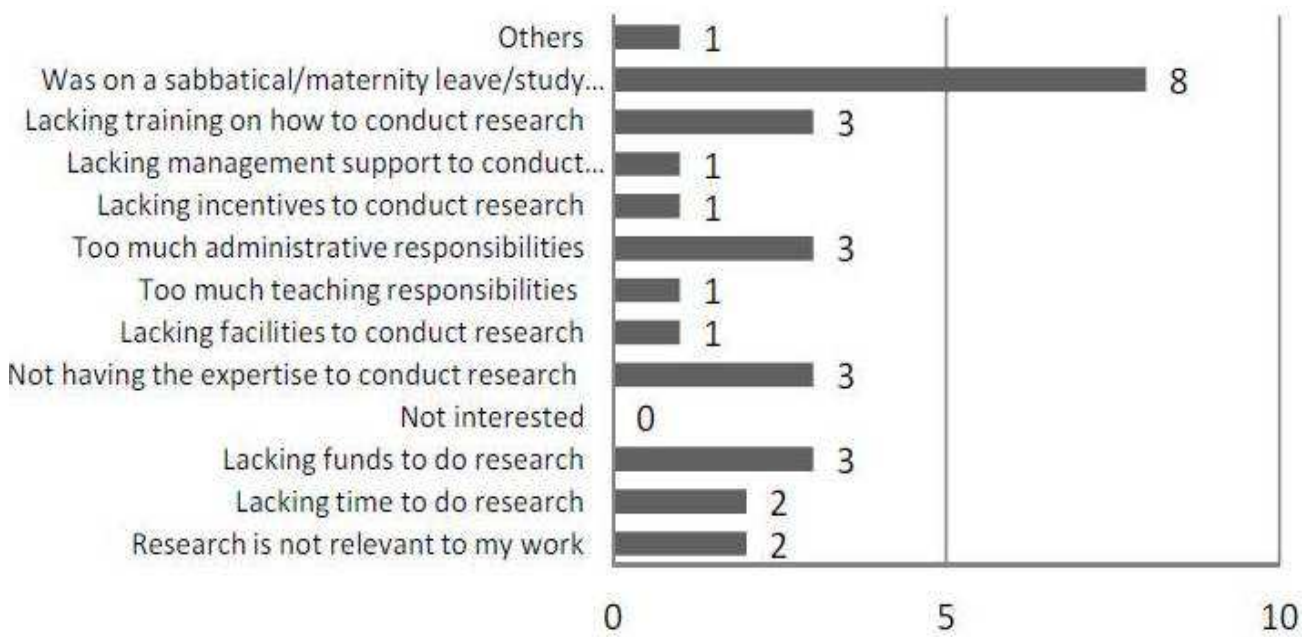

Figure 11: Reasons for Not Conducted Research for the Past Five Years (2006 - 2010) University

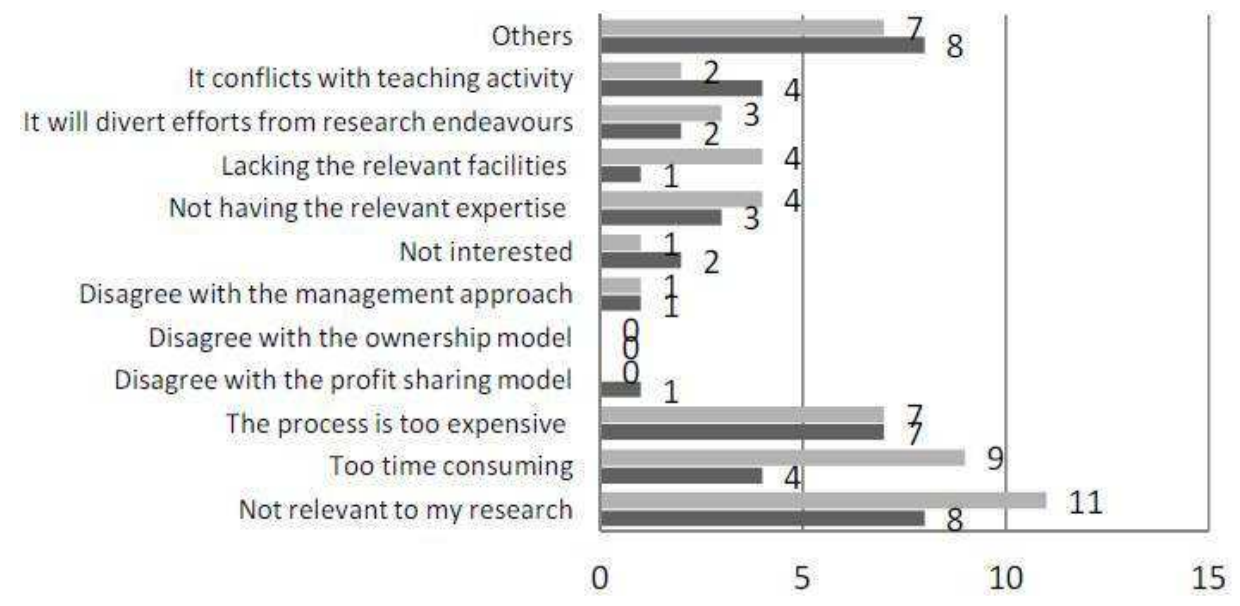

Figure 12: Reasons for Not Conducted Research with Output Led to IPR Filing and Not Having Commercialised Research Output for the Past Five Years (2006 - 2010) University

Further research is required into the key success factors affecting university research in Malaysia in order to identify, clearly, guidelines for the success of researchers. Figures 6 and 7 give insights into UTM researchers' attitudes and time management, but reveal nothing about the perceived adequacy of financial rewards or the need for more time for research. The danger is that more Malaysian academics will go overseas. A “... survey of 503 American business schools found that a newly-hired academics can expect a salary of $\$ 169,000$. At a midranking school, salaries of $\$ 250,000$ and above are common. That's just for nine months: plenty of time for books, consulting and visiting professorships during the long summer vacation" (Anon, 2011). Of course, most of the respondents were not from a business school, but the importance of financial rewards and sufficient time allocation for research requires further investigation. 


\section{Conclusions}

The descriptive case study has revealed that what lies behind UTM's success are:

- A structure that had been designed to drive research activities.

- Researchers who are also pursuing IP filing and commercialization which can be the catalyst to get other researchers to follow suit.

- The researchers have positive opinion regarding the university and the government in terms of provision of support frameworks and incentives for research activities.

Several dilemmas or disadvantages that can slow down the high performance achievement among researchers in the context of Malaysia higher education institutions can also be identified in this study. The findings reveal that almost twothirds of the researchers are loaded with teaching undergraduate and postgraduate programmes as well as administrative duties. A number of the researchers also reveal that commercialization is not relevant to their work or if it was, then commercialization itself is perceived as time consuming and expensive. The findings of this study can also provide some necessary guidelines for the avoidance of the disadvantages or guidelines for the continuous success of all researchers. Other higher education institutions in Malaysia are suggested to re-examine the balance between administrative and teaching duties to ensure that sufficient amount of time can be aimed at spurring research work. The case study approach does not naturally lend itself to generalizations. Further work needs to be done in order to find meaningful causal relationships between the explored factors above and universities' research performance. This research being focused on one university, it would be useful to replicate the study of other universities in Malaysia. This may lead towards some findings that can be generalized.

\section{Acknowledgment}

We wish to acknowledge the anonymous reviewers for their valuable comments and insights. The Malaysian Ministry of Higher Education (MOHE) for the research grant (Fundamental Research Grant Scheme (FRGS)) enabling this study to be carried out. Dr. Kamariah Ismail, the Deputy Dean for Commercialisation, Innovation and Commercialisation Centre, Universiti Teknologi Malaysia, for the interview and information shared.

\section{References}

Andersson, T. (2010). Public Research and University Reform - European Perspectives. Discussion paper for the Workshop on "University Organisation, Excellence, and Societal Impacts". 5 August 2010. Kuala Lumpur.

Anonymous. (2011). "Trouble in the Middle: Is Time Running Out for Business Schools that aren't Quite Elite?," The Economist, 1521 October 2011. pp. 57 - 58.

Candell, A. \& Jaffe, A. B. (1999). 'The Regional Economic Impact of Public Research Funding: A Case Study of Massachusetts,' In L. M. Branscomb, F. Kodama \& R. Florida. Industrializing Knowledge. US: MIT press. pp. 510-530.

Damon, W. W. (2011). "The Research University: Allocating Resources within Schools and among Schools," Proceedings of the American Institute of Higher Education 6th International Conference. 6-8 April 2011. Charleston. pp. 395-406.

Eisenhardt, K. M. (1989). "Building Theories from Case Study Research," Academy of Management Review. vol. 14. pp. 532-550.

James, E. (1990). 'Decisions Processes and Priorities in Higher Education,' In Hoenack, S.A. and E.L. Collins. (Eds.). The Economics of American Universities: Management, 
Operations, and Fiscal Environment. Albany: State University of New York Press.

Lamari, M. \& Jacob, J. L. (2011). Factors Associated with Research Productivity of Education Faculty: An Econometric Analysis of the Publication Performances within Quebec Universities, 2001-2008. Proceedings of EDULEARN11 Conference. 4-6 July 2011, Barcelona, pp. 7080.

March, J. G. (1991). "Exploration and Exploitation in Organizational Learning," Organization Science. Vol. 2. No. 1. pp. 71-87.

Massy, W. F. (1996). Resource Allocation in Higher Education. Ann Arbor: University of Michigan Press.

McMillan, J. H. \& Schumacher, S. (1997). Research in Education: A Conceptual Introduction. New York: Longman.

MOHE (Ministry of Higher Education). (2008). 'R\&D Products of Public Universities in Malaysia: Commercialized Products,' Products with Commercial Potential, Patents and Trademarks (Until August 2008). Ministry of Higher Education. Malaysia.

Nordin, M. R. (2001). 'The Challenge for Higher Education in Malaysia in an Era of a Knowledge-based Economy," In Abdulai, D. N. (Ed). Malaysia and the K-Economy. Pelanduk: Malaysia. pp. 25-27.

OECD. (1994). The Measurement of Scientific and Techniological Activities. Paris: OECD.

Rapoport, R. N. (1970). "Three Dilemmas in Action Research," Human Relations, Vol. 23. pp. $499-513$.
Roca, J., Bikfalvi, A., Simon, A. \& Alcoba, 0. (2011). "Knowledge Transfer Management as a Tool for Enhancing Research Teams Performance," Proceedings of EDULEARN11 Conference. 4-6 july 2011, Barcelona, pp. 4854-4861.

Stake, R. (1995). 'The Art of Case Research,' Thousand Oaks: Sage Publications.

Teddlie, C. \& Yu, F. (2007). "Mixed Methods Sampling: A Typology with Examples," Journal of Mixed Methods Research, Vol. 1. No. 1. pp. 77-100.

World Bank. (2000). 'Higher Education in Developing Countries: Peril and Promise,' The task Force on Higher Education and Society. Washington: The World Bank. (ISBN: 0-8213-4630-X).

Yin, R. K. (1994). Case Study Research: Design and Methods. 2nd. Ed. Beverly Hills: Sage Publishing.

Yin, R. K. (2003). Applications of Case Study Research. 2nd Ed. Beverly Hills: Sage Publishing. 